\title{
Pemanfaatan Ekstrak Daun Mangga (Mangifera foetida L.) sebagai Penurun Asam Urat dalam Biji Melinjo
}

\author{
Pramudia Bagus Dewangga $^{1}$, Ulys Larasati², Siti Salamah ${ }^{3 *}$ \\ ${ }^{1}$ Program Studi Teknik Kimia FTI UAD, Kampus III, J1. Supomo, Janturan, Warungboto, Yogyakarta 55164 \\ Universitas Ahmad Dahlan \\ *email: sitisalamah@che.uad.ac.id
}

\begin{abstract}
Melinjo plants including the types of old plants. Uric acid is the final metabolisme result of purine, purine is one of the components of nucleic acids contained in the body of the cell nucleus. Gout disease to result from consume excessive of purine substances. This reaserch to reduce uric acid levels in seeds melinjo order melinjo seeds can be processed into refined products chips with low uric acid using blanching method from mango leaf extract.

This research was making young mango leaf extract using distillate water as a solvent. Melinjo seeds that have been peeled after then process blanching is carried out using a preliminary heating at a temperature of less than $80-90{ }^{\circ} \mathrm{C}$ for 8 minute, using young mango leaf extract. Water immersion Melinjo is filtered, then analyzed in the Clinical Pathologyn Laboratory University of Gadjah Mada.This research was conducted with seed weight variable 10, 20, 30, 40, 50, 60 grams. Other variabels such as differences in the length of time 20,40,60,80,100,120 minutes. From the preliminary data showed that levels of uric acid in the melinjo seed is $222 \mathrm{mg} / 100 \mathrm{~g}$.

The result of this research were the highest decrease in uric acid levels using variable melinjo seed weight $10 \mathrm{gr}$ with immersion time of 30 ' is $17.86 \%$. Using seed weight $10 \mathrm{gr}$ melinjo carried back to the old variable immersion study obtained results decreased levels of uric acid melinjo seed with most optimal immersion time is 100' with a decrease of $18.43989 \%$.
\end{abstract}

Keywords: mlinjo seed, blanching, uric acid

\section{Pendahuluan}

Melinjo merupakan tanaman asli Indo - Malaya, tanaman ini sering ditemukan dalam daerah kering dan hutan basah. Khususnya di Indonesia ${ }^{[1]}$. Biji melinjo dan produk olahannya seperti emping melinjo merupakan produk yang paling populer. Kesukaan konsumen terhadap emping melinjo mulai menurun disebabkan zat purin yang terkandung didalamnya relatif tinggi. Purin mempunyai senyawa turunan yaitu hipoxantina, xantina, teobromina, kafeina, isoguanina, dan asam urat.

Asam urat adalah produk akhir dari katabolisme purin yang berasa dari degradasi nukleotida purin yang terjadi pada semua sel tetapi asam urat hanya dihasilkan oleh jaringan yang mengandung xhantineoxidase terutama di hepar dan usus kecil ${ }^{[2]}$. Kadar asam urat dalam darah harus dikontrol untuk meminimalkan efek merugikan. Tubuh menghilangkan asam urat dalam ginjal, dan sebagian juga melalui usus, untuk menjaga konsentrasi pada tingkat yang sehat dalam darah ${ }^{[3]}$. Penyakit asam urat adalah jenis penyakit artritis yang di sebabkan oleh penumpukan kristal akibat tingginya kadar asam urat dalam tubuh. Sendi - sendi yang diserang adalah jari - jari kaki, dengkul, tumit, pergelangan tangan, jari tangan, dan siku [4]. Oleh karena itu, untuk mengatasi asam urat dalam biji melinjo menjadikan hal yang menarik diteliti dengan demikian masalah tentang penyakit asam urat dapat diturunkan. Asam urat adalah senyawa alkaloid yang termasuk dalam grup basa nitrogen ${ }^{[5]}$. Sifat dari alkaloid adalah mudah larut air dalam bentuk garamnya ${ }^{[6]}$. Dengan mengubah asam urat yang bersifat basa menjadi garam (deprotonisasi $-\mathrm{OH}$ ) larut air dengan cara penambahan ekstrak daun mangga (Mangifera foetida L. $)^{[7]}$ yang diperoleh dari 2 metode ekstraksi digesti (maserasi kinetik dengan pengadukan kontinu pada temperatur yang lebih tinggi dari suhu kamar ) diharapkan dapat mengurangi kandungan asam urat dalam biji melinjo serta menganalisa kadar asam urat menggunakan spektrofotometer dengan metode Fluitest Uric Acid ${ }^{[8]}$.

Penelitian ini bertujuan untuk menurunkan kadar asam urat pada biji melinjo dengan menggunakan ekstrak daun mangga dengan variabel berat biji melinjo dan variabel waktu perendaman serta menguji 
tingkat kesukaan responden terhadap emping dari biji melinjo yang setelah proses penurunan kadar asam urat.

\section{Metodologi}

Bahan-bahan yang digunakan adalah daun mangga, biji melinjo dan Aquadest. Alat-alat yang digunakan dalam percobaan ini adalah Neraca analitis, Gelas ukur, Gelas beker, Pipet ukur, Propipet, Kaca arloji, Termometer, Magnetic stirrer, Pisau, Corong, Pot Sampel, satu set rangkaian alat ektraksi, Spektrofotometer, dan GC MS Shimadzu.

Metode penelitian yang digunakan adalah metode eksperimen dengan Rancangan Acak Kelompok (RAK) pola Faktorial yang terdiri dari 2 faktor. Faktor pertama adalah berat biji melinjo (A) dengan berat 10 , 20, 30, 40, 50, 60 gram. Faktor kedua adalah waktu perendaman (B) dengan waktu 20, 40, 60, 80, 100, 120 menit. Penelitian dilakukan dengan beberapa tahap, meliputi:

A. Tahap Penentuan Kadar Ester Ekstrak Daun Mangga

Mencuci daun mangga muda dan tua hingga bersih, kemudian ditiriskan. Memotong daun mangga muda dan tua $3-4 \mathrm{~cm}$, kemudian menimbang daun mangga tersebut masing-masing 10 gr, kemudian masukkan ke gelas beker. Menambahkan Aquadest $100 \mathrm{ml}$ ke gelas beker masing-masing. Membuat ekstrak daun mangga dengan proses ekstraksi digesti. Dengan suhu ekstraksi $80-90{ }^{\circ} \mathrm{C}$, waktu 60 menit. Menyaring hasil ekstrak daun manga dan menganalisis ester (asam asetat) dengan alat GC-MS.

B. Tahap Pembuatan Ekstrak Daun Mangga Muda

Mencuci daun mangga muda hingga bersih, kemudian ditiriskan dan memotong $3-4 \mathrm{~cm}$. Menimbang daun tersebut 120 gr, kemudian masukkan ke gelas beker.

Menambahkan Aquadest $1200 \mathrm{ml}$ (dilakukan pada 2 kali pada gelas beker $600 \mathrm{ml}$ ). Membuat ekstrak daun mangga dengan proses ekstraksi digesti. Dengan suhu ekstraksi $80-90{ }^{\circ} \mathrm{C}$, waktu 30 menit serta menyaring hasil ekstrak daun mangga.

C. Tahap Penurunan Asam Urat Dengan Variabel Berat Biji Melinjo dan Waktu perendaman Mengupas kulit terluar dan membersihkan biji melinjo. Menimbang biji melinjo (10, 20, 30, 40, 50, 60 gram). Memasukan biji melinjo yang telah bersih ke dalam gelas beker, kemudian memasukkan ekstrak daun mangga $100 \mathrm{ml}$. Melakukan proses blansing dengan waktu 8 menit; suhu $80-90^{\circ} \mathrm{C}$.

Merendam biji melinjo dengan waktu perendama 30 menit. Percobaan untuk variabel waktu perendaman diulang dengan berat biji melinjo 10 gram, diperlakukan sama dengan waktu perendaman $(20,40,60,80,100,120$ menit). Selanjutnya larutan hasil perendaman dianalisis dengan Fluitest Uric Acid.

D. Tahap Uji Organoleptik Emping Dari Biji Melinjo Yang Telah Direndam Diujikan Kepada Responden.

Mencuci biji melinjo yang telah direndam ekstrak air daun mangga muda.Mengoven biji melinjo yang telah direndam (10 menit, suhu $100{ }^{\circ} \mathrm{C}$ ).Memipihkan Biji Melinjo dengan cara dipukul - pukul hingga tipis.Mengoven biji melinjo yang telah direndam ekstrak air daun mangga (5 menit, suhu 100 $\left.{ }^{\circ} \mathrm{C}\right)$.Manggoreng emping biji melinjo dengan minyak panas ${ }^{[9]}$, kemudian ditiriskan dan mengujikan biji melinjo secara sensoris kepada responden.

\section{Hasil dan Pembahasan}

Sampel penelitian pendahuluan berupa penelitian tentang kandungan asam asetat dalam daun mangga yang diperoleh dari pohon mangga yang berada di lingkungan gg.satria, janturan, Yogyakarta. Pertama penelitian menggunakan dua sampel daun mangga yang terdiri sampel daun mangga muda (DM) dan daun mangga tua (DT) dari dua sampel tersebut ditimbang masing-masing sebanyak 10 gram kemudian dilakukan ekstraksi menggunakan pelarut aquadest $100 \mathrm{ml}$ selama 60 menit dengan suhu ekstraksi 80 - 90 ${ }^{\circ} \mathrm{C}$. Hasil Analisis dapat dilihat pada gambar 1 berikut: 


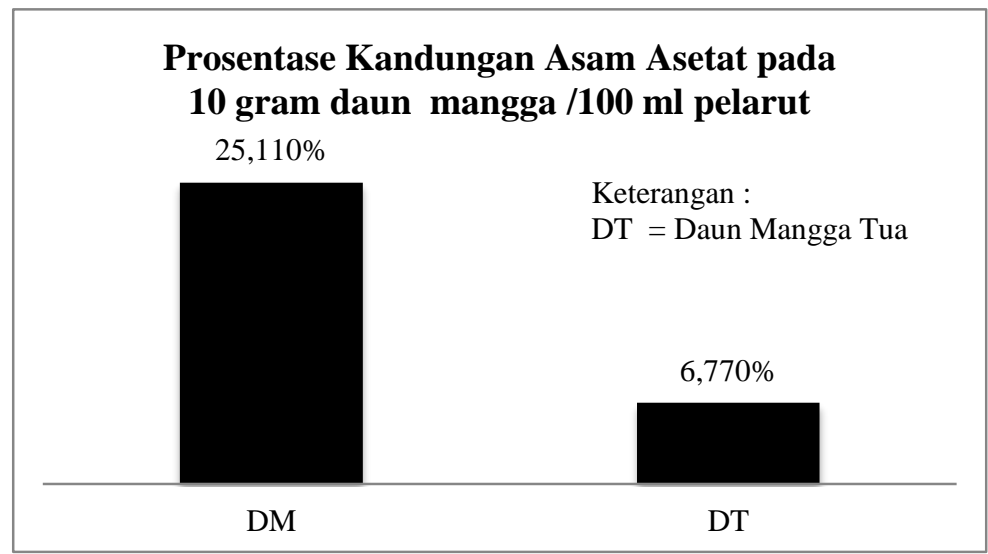

Gambar 1. Grafik Prosentase Asam Asetat Dalam Daun Mangga Muda (DM) dan Daun Mangga Tua (DT)

Berdasarkan hasil analisis diatas, analisis dilakukan dengan menggunakan GCMS didapatkan kandungan asam asetat dalam daun mangga muda sebesar 25,11 \% / 10 gr/ 100ml sedangkan kandungan asam asetat dalam daun mangga tua sebesar 6,77 \% / 10gr/100ml, Pelarut yang digunakan yaitu daun muda, karena kandungan asam asetat yang lebih banyak. Hasil analisis GCMS kandungan asam asetatdalam daun mangga terdapat pada gambar 2 dan gambar 3 berikut :

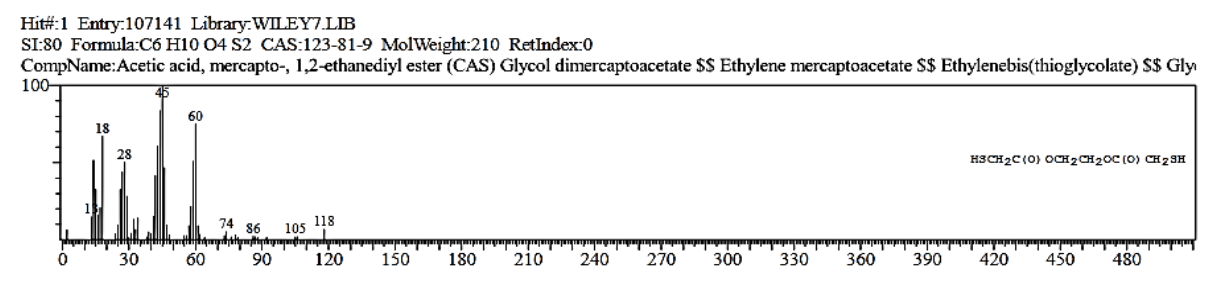

Gambar 2. Kromatogram GCMS Asam Asetat dalam daun Mangga Muda

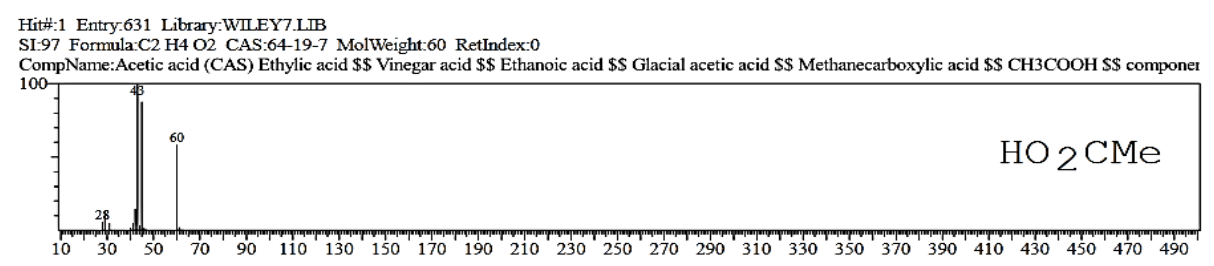

Gambar 3. KromatogramGCMS Asam Asetat Dalam Daun Mangga Tua

Dari gambar 2 dan 3 nampak bahwa kandungan asam asetat banyak terkandung dalam daun mangga muda sehingga pelarut yang digunakan adalah ektrak daun mangga muda.

Setelah penentuan pelarut, penelitian dilanjutkan dengan menggunakan variabel berat biji melinjo yaitu 10gr ; 20gr ; 30gr ; 40gr ; 50gr dan 60gr. Dengan pelarut masing-masing 100ml. Perendaman dilakukan selama 30 menit. Hasil analisis dapat dilihat pada tabel 1 sebagai berikut:

Tabel 1. Hasil Analisis Asam Urat Variabel Berat Biji Melinjo

\begin{tabular}{ccc}
\hline \multirow{2}{*}{ Berat Biji Melinjo } & \multicolumn{2}{c}{ Asam Urat } \\
\cline { 2 - 3 } & Abs & Hasil ( mg/dl ) \\
\hline 10 gram & 0,12 & 4 \\
20 gram & 0,115 & 3,83 \\
30 gram & 0,11 & 3,67 \\
40 gram & 0,085 & 2,83 \\
50 gram & 0,9 & 3 \\
60 gram & 0,9 & 3 \\
\hline
\end{tabular}


Hasil analisis asam urat pada tabel 1, kemudian dilakukan perhitungan. Hasil perhitungan dapat dilihat pada tabel 2 sebagai berikut:

Tabe 2. Hasil Perhitungan Penyusutan Kadar Asam Urat Dalam Biji Melinjo

\begin{tabular}{cccc}
\hline $\begin{array}{c}\text { Berat Melinjo } \\
(\mathrm{gram} / 100 \mathrm{ml})\end{array}$ & $\begin{array}{c}\text { Kadar Awal / gram } \\
\text { biji }\end{array}$ & $\begin{array}{c}\text { Kadar As.Urat Yang } \\
\text { Terambil }\end{array}$ & \% Penyusutan \\
\hline 10 & 1,32 & 0,24 & 17,86 \\
20 & 2,64 & 0,23 & 8,55 \\
30 & 3,96 & 0,22 & 5,46 \\
40 & 5,29 & 0,17 & 3,16 \\
50 & 6,61 & 0,18 & 2,68 \\
60 & 7,87 & 0,18 & 2,25 \\
\hline
\end{tabular}

Dari tabel 2 diatas didapat hasil asam urat yang mengalami penyusutan terbanyak yaitu pada berat biji melinjo 10 gram sebesar $4 \mathrm{mg} / \mathrm{dl}$. Maka didapat hasil prosentasi penyusutan asam urat sebesar 17,86 \%. Apabila berat biji melinjo semakin banyak dengan jumlah pelarut yang sama, maka asam urat yang terambil oleh pelarut lebih sedikit, hal ini kemungkinan disebabkan adanya pengaruh dari luas permukaan biji melinjo yang kontak dengan pelarut. Hasil analisis dengan menggunakan variabel waktu perendaman yaitu $20 ; 40$; $60 ; 80 ; 100$ dan 120 menit dengan berat biji melinjo masing-masing 10gramdapat dilihat pada tabel 3 berikut :

Tabel 3. Hasil Analisis Asam Urat Variabel Lama Perendaman

\begin{tabular}{ccc}
\hline \multirow{2}{*}{ Waktu Perendaman } & \multicolumn{2}{c}{ Asam Urat } \\
\cline { 2 - 3 } & Abs & Hasil ( mg/dl ) \\
\hline 20 Menit & 0,1 & 3,5 \\
40 Menit & 0,1 & 3,67 \\
60 Menit & 0,11 & 3,88 \\
80 Menit & 0,11 & 4 \\
100 Menit & 0,12 & 4,13 \\
120 Menit & 0,12 & 4,13 \\
\hline
\end{tabular}

Dari hasil analisis asam urat pada tabel 3 kemudian dilakukan perhitungan. Hasil perhitungan dapat dilihat pada tabel 4sebagai berikut:

Tabel 4. Hasil Prosentasi Penyusutan Kadar Asam Urat Dalam Biji Melinjo

\begin{tabular}{cccc}
\hline Waktu Perendaman & $\begin{array}{c}\text { Kadar Awal / gram } \\
\text { biji }\end{array}$ & $\begin{array}{c}\text { Kadar As.Urat Yang } \\
\text { Terambil }\end{array}$ & \% Penyusutan \\
\hline 20 Menit & 1,32 & 0,15627 & 15,62703 \\
40 Menit & 1,32 & 0,163861 & 16,38605 \\
60 Menit & 1,32 & 0,173237 & 17,32368 \\
80 Menit & 1,32 & 0,178595 & 17,85946 \\
100 Menit & 1,32 & 0,184399 & 18,43989 \\
120 Menit & 1,32 & 0,184399 & 18,43989 \\
\hline
\end{tabular}

Dari tabel 4 diatas didapat hasil asam urat yang paling banyak terambil pada berat biji melinjo 10 gram dengan waktu perendaman yang paling baik yaitu 100 menit, asam urat yang terambil sebesar 3,5 $\mathrm{mg} / \mathrm{dl}$. Maka didapat hasil prosentasi penyustan asam urat sebesar 18,43989\%. Apabila perendaman biji melinjo semakin lama, maka asam urat yang terambil oleh pelarut akan mengalami kondisi jenuh, dimana prosentase penyusutan asam urat tetap sebesar 18,43989 \%, sehingga dapat disimpulkan bahwa penurunan asam urat yang optimal dengan berat biji melinjo 10 gram dengan waktu perendaman 100 menit menggunakan $100 \mathrm{ml}$ pelarut. Biji melinjo selanjutnya dibilas dengan aquadest untuk menghilangkan pelarut, kemudian di oven untuk menghilangkan kadar air seminimal mungkin agar biji melinjo tahan dalam penyimpanan. Pengovenan dilakukan pada suhu $100{ }^{\circ} \mathrm{C}$ selama 10 menit. Setelah pengovenan biji 
dibersihkan kulit arinyakemudian digeprek / dipipihkan untuk dijadikan emping. Hasil pembuatan biji melinjo terdapat pada gambar 4 berikut ini :

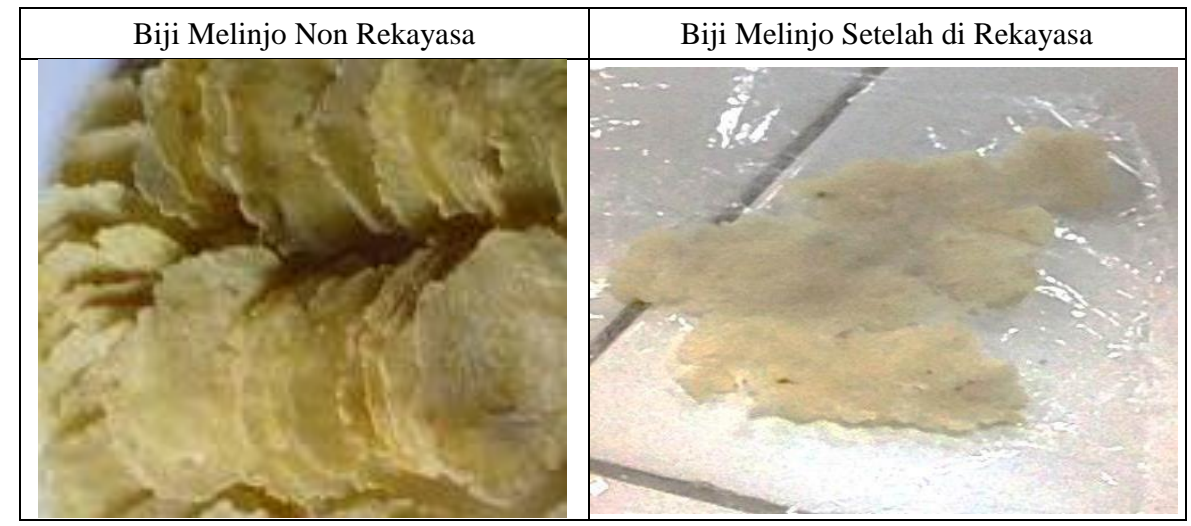

Gambar 4. Hasil pemipihan Biji Melinjo Non Rekayasa dan Rekayasa Penurunan asam urat

Emping biji melinjo yang sudah digeprek / dipipihkan kemudian di oven kembali dengan suhu $100^{\circ} \mathrm{C}$ selama 5 menit atau dapat juga dilakukan pengeringan menggunakan sinar matahari bila memungkinkan. Emping dari biji melinjo siap untuk digoreng dan siap diujikan kepada responden.

Jenis uji organoleptik yang digunakan yaitu uji kesukaan (hedonik). Sampel yang digunakan dalam uji organoleptik ini adalah emping biji melinjo yang diturunkan asam uratnya (Rekayasa) dan emping biji melinjo yang tidak turunkan asam uratnya (Non Rekayasa ). Karakteristik organoleptik yang dinilai adalah warna, aroma dan rasa dari emping biji melinjo. Skala hedonik yang digunakan adalah (1) tidak suka, (2) biasa, (3) agak suka, (4) sukadan (5) sangat suka. Penerimaan emping biji melinjo didapat dengan mengakumulasikan kesukaan responden terhadap emping biji melinjo. Pernyataan (2) agak suka, (3) suka, dan (4)sangat suka yang diberikan oleh responden menunjukkan bahwa produk yang diuji masih dapat diterima secara fisik dan cenderung sama dengan produk sejenis yang tersedia di pasaran. Responden pada uji ini adalah mahasiswa yang berada disekitarkampus 3 Universitas Ahmad Dahlan Yogyakarta. Pelaksanaan pengujian dilakukan di lingkungan kampus 3 Universitas Ahmad Dahlan Yogyakarta. Jumlah responden pada uji kesukaan ini adalah sebanyak 26 responden. Responden diminta untuk memberi penilaian terhadap warna, aromadan rasa emping biji melinjo yang diujikan. Uji kesukaan emping biji melinjo dilakukan dengan tiga parameter yaitu warna, aromadan rasa. Hasil uji organoleptik dapat dilihat pada tabel 5,6 dan 7 sebagai berikut :

Tabel 5. Hasil Uji Organoleptik Warna

\begin{tabular}{ccc}
\hline Tingkat Kesukaan & \multicolumn{2}{c}{ Responden } \\
\cline { 2 - 3 } Warna & Emping Biji Melinjo Rekayasa & Emping Biji Melinjo Non Rekayasa \\
\hline Tidak Suka & 1 & 0 \\
Biasa & 2 & 0 \\
Agak Suka & 7 & 0 \\
Suka & 10 & 10 \\
Sangat Suka & 6 & 16 \\
Total & 26 & 26 \\
\hline
\end{tabular}


Tabel 6. Hasil Uji Organoleptik Aroma

\begin{tabular}{ccc}
\hline Tingkat Kesukaan & \multicolumn{2}{c}{ Responden } \\
\cline { 2 - 3 } Aroma & Emping Biji Melinjo Rekayasa & Emping Biji Melinjo Non Rekayasa \\
\hline Tidak Suka & 0 & 0 \\
Biasa & 4 & 1 \\
Agak Suka & 1 & 1 \\
Suka & 17 & 20 \\
Sangat Suka & 4 & 4 \\
Total & 26 & 26 \\
\hline
\end{tabular}

Tabel 7. Hasil Uji Organoleptik Rasa

\begin{tabular}{ccc}
\hline Tingkat Kesukaan & \multicolumn{2}{c}{ Responden } \\
\cline { 2 - 3 } Rasa & Emping Biji Melinjo Rekayasa & Emping Biji Melinjo Non Rekayasa \\
\hline Tidak Suka & 0 & 1 \\
Biasa & 2 & 3 \\
Agak Suka & 2 & 1 \\
Suka & 13 & 13 \\
Sangat Suka & 9 & 8 \\
Total & 26 & 26 \\
\hline
\end{tabular}

Dari tabel 5, 6 dan 7kemudian diolah menggunakan Uji statistik non parametrik Kruskal-Wallis dengan alat hitung SPSS 17.0.

\section{Warna}

Warna pada suatu produk menjadi kesan awal terciptanya penilaian terhadap suatu produk makanan. Oleh sebab itu, warna merupakan parameter yang penting bagi penampakan produk secara keseluruhan. Sebaran tingkat kesukaan responden terhadap warna emping biji melinjo yang diturunkan asam uratnya (Rekayasa) dan emping biji melinjo yang tidak diturunkan asam uratnya (Non Rekayasa) disajikan pada tabel 8 berikut:

Tabel 8. Sebaran tingkat kesukaan responden terhadap warna emping biji melinjo

\begin{tabular}{ccc}
\hline Tingkat Kesukaan & \multicolumn{2}{c}{ Prosentase Kesukaan Warna } \\
\cline { 2 - 3 } Warna & $\begin{array}{c}\text { Emping Biji Melinjo Rekayasa } \\
(\%)\end{array}$ & $\begin{array}{c}\text { Emping Biji Melinjo Non Rekayasa } \\
(\%)\end{array}$ \\
\hline Tidak Suka & 3,85 & 0,00 \\
Biasa & 7,69 & 0,00 \\
Agak Suka & 26,92 & 0,00 \\
Suka & 38,46 & 38,46 \\
Sangat Suka & 23,08 & 61,54 \\
Total & 100 & 100 \\
\hline
\end{tabular}

Dari tabel 8, menunjukkan bahwa lebih dari separuh jumlah responden $(38,46 \%)$ suka terhadap warna emping biji melinjo yang rekayasadan emping biji melinjo yang tidak Rekayasa. Terdapat 3 orang responden yang menyatakan tidak suka terhadapwarna emping biji melinjo yang direkayasa.

Uji Kruskal-Wallis menunjukkan tidak ada perbedaan yang nyata antara kesukaan responden terhadap warna emping biji melinjo yang diturunkan asam uratnya (Rekayasa) dan emping biji melinjo yang tidak turunkan asam uratnya (Non Rekayasa) $(\mathrm{p}=0,000)$. Hal ini menunjukkan bahwa tidak terdapat perubahan yang nyata pada warna emping biji melinjo yang diturunkan asam uratnya. Perbedaan tingkat kesukaan panelis terhadap warna emping biji melinjo tidak berarti bahwa warna emping biji melinjo yang diturunkan asam uratnya (Rekayasa) tidak dapat diterima oleh konsumen. 


\section{Aroma}

Aroma merupakan salah satu faktor yang menentukan mutu suatu produk. Aroma emping biji melinjo timbul dari senyawa yang terkandung dalam biiji melinjo tersebut, Senyawa organik yang sangat sensitif dalam biji, dan keseimbangan biokimia dari senyawa tersebut, akan mengalami destruksi oleh hampir semua variabel lingkungan di alam. Panas dan dingin, cahaya, oksigen, kelembaban, kekeringan, waktu, dan kandungan enzim dalam bahan pangan itu sendiri, semua cenderung merusakkan bahan pangan. Kerusakan bahan pangan biasanya ditandai dengan perubahan aroma pada bahan pangan tersebut ${ }^{[10]}$. Hasil uji kesukaan terhadap aroma emping biji melinjo disajikan pada tabel 9.

Tabel 9. Sebaran tingkat kesukaan responden terhadap aroma emping biji melinjo

\begin{tabular}{ccc}
\hline Tingkat Kesukaan & \multicolumn{2}{c}{ Prosentase Kesukaan Warna } \\
\cline { 2 - 3 } Aroma & $\begin{array}{c}\text { Emping Biji Melinjo Rekayasa } \\
(\%)\end{array}$ & $\begin{array}{c}\text { Emping Biji Melinjo Non Rekayasa } \\
(\%)\end{array}$ \\
\hline Tidak Suka & 0,00 & 0,00 \\
Biasa & 15,38 & 3,85 \\
Agak Suka & 3,85 & 3,85 \\
Suka & 65,38 & 76,92 \\
Sangat Suka & 15,38 & 15,38 \\
Total & 100 & 100 \\
\hline
\end{tabular}

Prosentase tingkat kesukaan responden terhadap aroma kedua jenis emping biji melinjo tidak berbeda jauh untuk masing-masing skala kesukaan (lihat tabel 9.). Hampir 1/6 dari total jumlah responden $(15,38 \%)$ menyatakan sangat suka terhadap aroma emping biji melinjo. Proporsi responden pada tingkat kesukaan suka, agak suka, dan tidak suka tidak berbeda jauh diantara kedua jenis emping biji melinjo. Uji Kruskal-Wallis menunjukkan tidak ada perbedaan yang nyata antara kesukaan terhadap aroma emping biji melinjo yang diturunkan asam uratnya (Rekayasa) dan emping biji melinjo yang tidak diturunkan asam uratnya (Non Rekayasa). Hal ini menunjukkan bahwa tidak terdapat perubahan yang nyata pada aroma emping biji melinjo setelah diturunkan asam uratnya. Kesukaan terhadap aroma emping biji melinjo sangat menentukan tingkat penerimaan terhadap aroma emping tersebut.

\section{Rasa}

Rasa pada suatu produk menjadi kesan awal terciptanya penilaian terhadap suatu produk makanan. Oleh sebab itu, rasa merupakan parameter yang penting bagi produk secara keseluruhan. Sebaran tingkat kesukaan responden terhadap rasa emping biji melinjo yang diturunkan asam uratnya dan emping biji melinjo yang tidak diturunkan asam uratnya disajikan pada tabel10.

Tabel 10. Sebaran tingkat kesukaan responden terhadap rasa emping biji melinjo

\begin{tabular}{ccc}
\hline Tingkat Kesukaan & \multicolumn{2}{c}{ Prosentase Kesukaan Rasa } \\
\cline { 2 - 3 } Aroma & Emping Biji Melinjo Rekayasa (\%) & Emping Biji Melinjo Non Rekayasa (\%) \\
\hline Tidak Suka & 0,00 & 3,85 \\
Biasa & 7,69 & 11,54 \\
Agak Suka & 7,69 & 3,85 \\
Suka & 50,00 & 50,00 \\
Sangat Suka & 34,62 & 30,77 \\
Total & 100 & 100 \\
\hline
\end{tabular}

Tabel 10. menunjukkan bahwa lebih dari separuh jumlah responden $(50,00 \%)$ suka terhadap rasa emping biji melinjo yang diturunkan asam uratnya (Rekayasa) dan emping biji melinjo yang tidak diturunkan asam uratnya (Non Rekayasa). Terdapat 3 orang responden yang menyatakan tidak suka terhadap rasa emping biji melinjo yang tidak diturunkan asam uratnya (Non Rekayasa). Uji Kruskal-Wallis menunjukkan tidak ada perbedaan yang nyata antara kesukaan responden terhadap warna emping biji melinjo yang diturunkan asam uratnya (Rekayasa) dan emping biji melinjo yang tidak diturunkan asam uratnya (Non Rekayasa) ( $\mathrm{p}=0,639)$. Hal ini menunjukkan bahwa tidak terdapat perubahan yang nyata pada rasa emping biji melinjo yang diturunkan asam uratnya (Rekayasa). Perbedaan tingkat kesukaan panelis terhadap rasa emping 
biji melinjo tidak berarti bahwa rasa emping biji melinjo yang diturunkan asam uratnya (Rekayasa) tidak dapat diterima oleh konsumen. Prosentase penerimaan responden terhadap rasa emping biji melinjo yang diturunkan asam uratnya (Rekayasa) dan emping biji melinjo yang tidak diturunkan asam uratnya (Non Rekayasa) disajikan pada gambar 5 berikut ini.

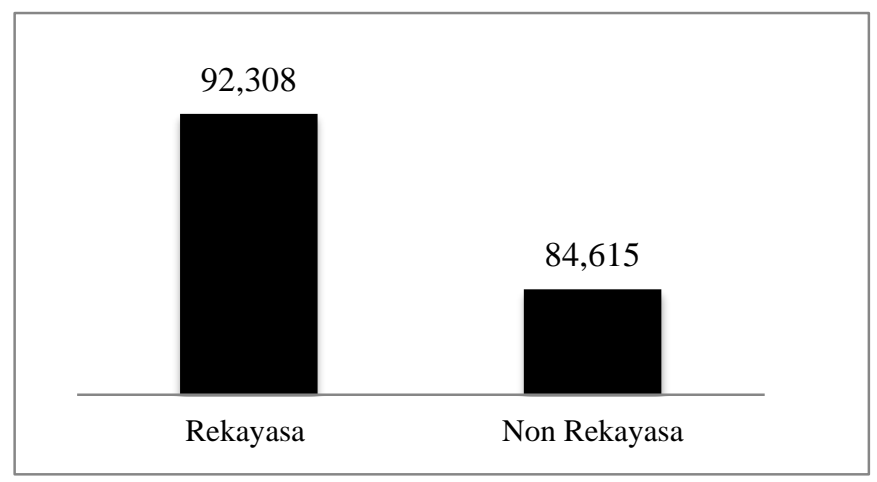

Gambar 5 . Grafik. Prosentase penerimaan responden terhadap rasa emping biji melinjo

Dari gambar 5 menunjukkan bahwa prosentase penerimaan responden terhadap rasa emping biji melinjo yang diturunkan asam uratnya (Rekayasa ) lebih besar dibanding prosentase penerimaan responden terhadap rasa emping biji melinjo yang tidak diturunkan asam uratnya (Non Rekayasa ). Skor modus tingkat kesukaan warna emping biji melinjo yang diturunkan asam uratnya (Rekayasa) adalah 5 (sangat suka) dengan prosentase penerimaan sebesar $92,31 \%$. Hal ini menunjukkan bahwa rasa emping biji melinjo yang diturunkan asam uratnya (Rekayasa) dapat diterima oleh konsumen.

\section{Kesimpulan}

Dari penelitian ini dapat disimpulkan sebagai berikut :

1. Daun manga muda dapat digunakan untuk menurunkan kadar asam urat dalam biji melinjo.Hasil analisis menunjukan kadar asam asetat tertinggi terdapat pada daun mangga muda $25,11 \%$ dan pada daun manga tua yaitu $6,77 \%$.

2. Penurunan kadar asam urat dalam biji melinjo dengan variabel berat biji melinjo yang optimal dengan berat biji melinjo 10 gr sebesar 17,86\% dengan waktu perendaman 30 menit.

3. Penurunan kadar asam urat dalam biji melinjo dengan variabel lama perendaman, didapatkan hasil yang optimal pada waktu 100 menit sebesar 18,43989\%. Uji Kesukaan pada biji melinjo yang telah dibuat emping, 26 responden menyatakan tidak ada perubahan yang signifikan dari segi warna, aroma dan rasa antara emping biji melinjo yang diturunkan asam uratnya (rekayasa) dan emping biji melinjo yang tidak diturunkan asam uratnya (non rekayasa).

\section{Daftar Pustaka}

[1] Kato H, Samizo M, Kawabata R, Takano F, \& Ohta T, 2011, Stilbenoids from the melinjo (Gnetum gnemon L.) fruit modulate cytokine production in murine peyer's patch cells ex vivo. Planta Med. 77(10):1027-1034.

[2] Zhao Y, Yang X, Lu W, Liao H \& Liao F. 2009. Uricase Based Methods for in Determination of Uric Acid in Serum. Microcim Acta, $164: 1-6$.

[3] Anonim, 2004, “Physiology and biochemistry of uric acid". National Center for Biotechnology Information, viewed 17 september 2013, http://www.ncbi.nlm.nih.gov/pubmed/15493112.

[4] Anonim, 2007, Pantangan dan anjuran bagi penderita asam urat, Majalah kesehatan, viewed 17 september 2013, http://majalahkesehatan.com/pantangan - dan-anjuran-bagi - penderita- asam-urat/.

[5] Akinpelu DA and Onakoya TM (2006). Antimicrobial activities of medicinal plants used in folklore remedies in south-western. Afr. J. Biotechnol., 5: 1078-1081.

[6] Hart H,2003,Kimia Organik,ed.2,Erlangga,Jakarta. 
[7] Hossain M., Ahmed M., and Islam A. 2010. Hypolipidemic and Hepatoprotective Effects of Different Fractions of Ethanolic Extract of Immature Leaves of Mangifera Indica (Linn.) in Alloxan Induced Diabetic Rats. IJPSR. Vol. 1 (11): 132-138.

[8] Kabuki T,Hakajima H, Arai M, Ueda S, Kuwabara Y and Dosako S. 2000. Characterization of novel anti microbial compounds from manggo ( mangifera indica L. ) Kernel seeds.Food Chemistry,71:61-66.

[9] Sandjaya, H. 2014. “ Buku Sakti Pencegahan \& Penangkal Asam Urat ”. Cetakan I.Mantra Books, Yogyakarta.

[10] Sunanto H, 2003, Budidaya Melinjo dan Usaha Produksi Emping, Penerbit Kanisius, Yogyakarta.

[11] Willey John, 2011. Hypouricemic Effects of Anthocyanin Extracts of Purple Sweet Potato on Potassiu Oxonate-induced Hyperuricemia in Mice. http://www.ncbi.nlm.nih.gov/pubmed/21433153, 7 Maret 2014. 